\title{
Short Text Messages to Motivate HIV Testing Among Men Who have Sex with Men: A Qualitative Study in Lima, Peru
}

\author{
Luis A. Menacho", ${ }^{*}$, Magaly M. Blas ${ }^{1,2}$, Isaac E. Alva ${ }^{1,2}$, E. Roberto Orellana ${ }^{3}$ \\ ${ }^{I}$ Epidemiology, HIV and STD Unit, School of Public Health and Administration, Universidad Peruana Cayetano \\ Heredia, Lima, Peru \\ ${ }^{2}$ NGO Via Libre, Lima, Peru \\ ${ }^{3}$ Schools of Social Work and Community Health, Portland State University, USA
}

\begin{abstract}
Objective: The objective of this study is to identify features and content that short message service (SMS) should have in order to motivate HIV testing among men who have sex with men (MSM) in Lima, Peru.

Methods: From October, 2010 to February, 2011, we conducted focus groups at two stages; six focus groups were conducted to explore and identify SMS content and features and two additional focus groups were conducted to tailor SMS content. The text messages were elaborated within the theoretical framework of the Information-MotivationBehavioral Skills model and the Social Support Theory.

Results: A total of 62 individuals participated in the focus groups. The mean age of participants was 28 years (range 1839). We identified important features and content items needed for the successful delivery of text messages, including: a) the use of neutral and coded language; b) appropriate frequency and time of delivery; c) avoiding mass and repetitive messages; and d) use of short, concise and creative messages. Although in Peru receiving text messages is usually a free service, it is important to remind participants that receiving messages will be free of charge.

Conclusion: Text messages can be used to promote HIV testing among Peruvian MSM. It is important to consider adequate frequency, message content and cost when delivering messages to promote HIV testing in this population.
\end{abstract}

Keywords: Cellular phone, men who have sex with men, HIV prevention, HIV testing, risk behaviors, text messaging.

\section{INTRODUCTION}

In Peru, the HIV epidemic is concentrated among men who have sex with men (MSM), among whom the HIV prevalence is estimated at $12.4 \%$ in Lima, the country's capital $[1,2]$. The proportion of HIV testing among this population is very low. Estimates show that less than $50 \%$ of MSM have been tested for HIV and that 50,000 individuals are not aware of their HIV positive status [1,3]. A timely diagnosis would allow participants to enroll earlier in the program that provides free highly active antiretroviral therapy.

In Peru, cell phones are promising tools to deliver HIVrelated interventions due to the high cell phone penetration (115\% by March 2012; some Peruvians have more than one cell-phone) and the interest MSM have in accessing HIV prevention interventions through this medium [4-6]. In an online study among Peruvian MSM, we found that $60.2 \%$ of participants wanted to receive HIV prevention interventions through their cell-phones [5]. Additionally, a study on HIV positive people in Peru found that most participants reported

*Address correspondence to this author at the Epidemiology, HIV and STD Unit, School of Public Health and Administration, Universidad Peruana Cayetano Heredia, Lima, Peru; Tel: +511 - 4818283;

E-mail: luchomenacho@gmail.com a willingness to use cell phones to receive messages regarding their HIV medication (74\%), and their sexual health $(81 \%)$, either by a pre-recorded voice or by short message service (SMS) [7]. Another study identified key features that text messages should have (such as being simple and concise and maintaining confidentiality and privacy by using coded words or phrases) to improve antiretroviral therapy adherence [8].

SMS allows for instantaneous delivery of messages directly to participants at any time, place, or setting via their phones. Participants can read the messages as soon as they receive them or store them until later [9]. Additionally, in settings such as Peru, participants do not need to pay to receive SMS, which makes it an inexpensive method to deliver health messages. Currently, there are multiple platforms such as www.elibom.com and www.clickatell.com that allow sending SMS messages to multiple recipients simultaneously at a very low cost. This makes the implementation of text messages for HIV prevention interventions feasible.

Text messages have been used for several purposes among MSM and the general population, for example: 1) as reminders for Hepatitis B vaccination and follow-up [10], 2) to motivate a reduction in methamphetamine use and highrisk sexual behaviors $[11,12], 3)$ to motivate HIV testing 
[13], and 4) to improve antiretroviral adherence among HIV positive people $[14,15]$.

Although, there is information regarding the features text messages should have to improve antiretroviral therapy adherence [8], there is limited information regarding features they should have to motivate HIV testing. The objective of this study is to identify content and features that text messages should have to motivate HIV testing among MSM in Lima, Peru.

\section{METHODS}

\section{Focus Groups Participants}

From October, 2010 to February, 2011, we conducted focus groups at two stages: 1) six focus groups were conducted to explore and identify SMS content and features that text messages should have to motivate HIV testing, and 2) two additional focus groups were conducted to tailor SMS content. In the first round of focus groups, two focus groups were conducted with self-reported, out-of-the-closet MSM, two with closeted gay-identified MSM, and two with MSM who self-identified as heterosexual. For the second round of focus groups we conducted one focus group with selfreported, out-of-the-closet MSM and one with closeted gayidentified MSM. Focus groups were stratified by age, with half of the focus groups conducted with participants 18-24 years old and half with participants 25 and older.

For the self-reported, out-of-the-closet MSM and closeted gay-identified MSM, we purposively recruited participants at a gay-serving community based organization (Epicentro) and for the MSM group who self-identified as heterosexual we recruited participants at billiard clubs frequented by this population. All venues were located in Lima, Peru. Participants received an incentive of 10 Peruvian nuevos soles for transportation (about \$4 US dollars) and a light meal for participating.

\section{Focus Groups}

A guide for the first round of focus groups was developed based on previous research about the reasons Peruvian MSM have for not getting tested for HIV, as well as research on SMS features for health promotion $[6-8,16$, 17]. The content validity of the focus group guide was established with consultants who have worked in HIV prevention and control. At the beginning of the focus group, participants were asked about their general knowledge of HIV, and any previous experiences receiving SMS. The initial discussion was followed by questions about advantages and disadvantages of using cell phones, including their opinions as to the best times and frequency to deliver messages. Finally, we focused on questions that elicited participants' preferences for how HIV-testing information should be delivered when using cell-phones. Based on the data collected during the first round of focus groups, we designed 18 preliminary text messages to be further developed in the second round of focus groups.

For the second round of focus groups, we showed the 18 messages to participants and asked them to elaborate on the following topics: 1) Did they think the messages achieved the goal of motivating HIV testing, 2) What aspects of the messages they liked/disliked, and, 3) how would they improve the messages. We used the participants' feedback to edit and finalize the text messages. All focus groups were conducted in Spanish by a trained moderator with experience in qualitative research. Groups lasted about one-and-a-half to two hours.

\section{Behavioral Theories}

The text messages were elaborated within the theoretical framework of the Information-Motivation-Behavioral (IMB) Skills model and the Social Support Theory. The IMB model, which has guided many HIV prevention and intervention studies, was used as the principal theoretical framework for tailoring messages. This model postulates that the promotion of HIV-preventive behaviors, such as HIV testing, requires the increase of knowledge, motivation and skills related to such behaviors $[18,19]$. The Social Support Theory postulates that the social support comprises tangible, emotional, and informational assistance, and companionship provided by members of one's social network [20]. This theory was used by Reback et al. to develop an intervention to reduce Methamphetamine use among MSM [11, 12].

\section{Data Management and Analysis}

Our analytical approach was guided by Glaser and Strauss' grounded theory (1967) and Padgett's recommendations for content analysis (2008) [21, 22]. As data from the initial focus groups became available, the research team met to review and identify emerging concepts and themes. We created thematic categories from which sets of codes were identified and used for subsequent transcript analyses. Throughout the analytic process, constant comparison was used to review information given by participants from the different MSM groups and age categories. This iterative approach was done in order to ensure that the most appropriate categories and themes were included in the analysis. After this, central messages were inductively derived from the statements made by participants and key informants $[23,24]$. We confirmed our findings by going back to the transcripts and identifying quotes that best illustrated common themes. Quotes were translated and edited for ease of reading, but were not substantially altered.

\section{Human Subjects Considerations}

The institutional review boards at Universidad Peruana Cayetano Heredia, and Via Libre approved the study. All participants gave verbal consent prior to their participation in the study, which was documented on the consent form by the signature of the researcher in charge of the consent process.

\section{RESULTS}

\section{Demographics}

Seventy-five individuals were invited to participate in the focus groups. A total of 62 (91.2\%) accepted to participate; 50 individuals participated in the first round of focus groups and 12 in the second round. Among the 62 participants, 25 were out-of-the-closet gay-identified MSM, 26 were closeted gay-identified MSM, and 11 were self-identified heterosexual MSM. The mean age of participants was 28 years (range 18-39). 


\section{Key Features to Tailor and Deliver SMS (Table 1)}

\section{General Perception}

In general, participants liked the idea of receiving messages on their cell phones with information about HIV prevention. The reasons given were that everyone has a cell phone and that the information received through this medium would be timely and confidential (quotes 1 and 2).

Most of the participants talked about negative experiences with SMS due to the constant sales and marketing promotions they received on their cell-phones (quote 3). However, participants reported no previous experiences in receiving health SMS messages.

\section{Messages at No Cost}

To ensure that individuals will subscribe to a program that delivers HIV prevention messages on their cell phones, participants reported that it is crucial to remind possible participants that the delivery of text messages will be free (quote 4).

\section{Potential Disadvantages of Text Messaging and How to Deal with Them}

As potential difficulties, participants identified that massive text messaging can be inappropriate and annoying for people (quote 5). Also, they said that participants can delete messages without reading them if they do not recognize the sender.

In order to avoid this situation, they suggested we should let users know that after subscribing to the project they will start receiving sporadic free messages; this will prevent that some participants delete messages before reading them (quote 6).

Another disadvantage is the possibility that someone close to the participant, such as a friend or a relative could read the message. For this reason is important to send coded messages that do not include sensitive words like HIV or clinic (quote 7).

\section{Frequency and Time}

For the purpose of encouraging HIV testing, participants said they would prefer to receive messages once a week, or two at the most in case they need to receive a special reminder. They reiterated that mass delivery must be avoided (quote 8). Participants recommended that some messages should be sent on "special days", for example messages about condom use should be sent before the weekends when participants are more likely to engage in risky sex. Messages about HIV testing should be sent at the beginning of the week, so participants can schedule their appointment at the clinic.

Regarding the timing, participants reported that by the end of the day on weekdays (quote 9) or anytime during weekends would be a better time to receive SMS, because these are times when users are more relaxed and not too busy to $\log$ onto the website, for instance, to make an appointment for HIV testing.

\section{Content}

Participants agreed that messages must be short and creative (quote 10).
When inviting for HIV testing, it is important to include words like "free" and "confidential" to make the invitation more attractive (quote 11).

They preferred a neutral language to ensure privacy, in case someone else read the message. Using coded words can be helpful (quote 12).

Messages must be different and not repetitive, and should not be only about HIV testing. Other complementary topics such as sexual health, friendship, or living with a partner should be included to attract participants' attention (quotes 13 and 14).

Participants also suggested adding a URL at the end of the messages so they can search later for more information about the program (quote 15).

Finally, participants reported that humorous messages should also be included because they help to remember important messages and situations (quote 16).

\section{Text Messages}

Text messages were not stratified by age or selfidentification because we found similar results across different age categories and MSM groups. Messages were organized as follows: complementary messages (4) that included a welcome message (1) and HIV prevention messages (3), messages addressing negative consequences related to being HIV positive (3), lack of knowledge about free testing (1) and treatment (1), messages related to discrimination and lack of support (4), and messages to increase risk perception (6). The messages oriented to motivate HIV testing among MSM organized by reasons for not getting tested [16] and component of the IMB Model $[18,19]$ are (Table 2).

\section{DISCUSSION}

We collected information regarding short text messages content and features to motivate HIV testing among MSM and finally designed and tailored messages to be used in future interventions. We identified several key themes for the successful delivery of SMS messages such as: using coded and neutral language, appropriate frequency and time, avoiding massive and repetitive messages, and use short, concise and creative messages. Although in Peru receiving text messages is usually a free service, it is important to remind when enrolling participants, and throughout the process, that messages received through the intervention will be free.

Coded and neutral language is important to protect the confidentiality of participants. Previous studies that used SMS for motivating a sensitive behavior change such as stopping drug use, taking antiretroviral medication or using condoms have also found that coded and neutral language should always be present during the intervention $[8,12]$. Cell phones can get lost or can occasionally be used by a friend or relative, thus by using codes we assure participants that we are taking measures to protect their privacy.

Our findings on the preferred frequency of receiving messages (once or twice a week) suggest that the objective of cell phone-based interventions to motivate HIV testing among MSM can be achieved with one or two messages per 
Table 1. Participant's Quotes with Regard to Key Features SMS Messages Should have to Motivate HIV Testing Among MSM

\begin{tabular}{|c|c|}
\hline Number of Quote & Representative Quotes \\
\hline Quote 1 & I would like to receive SMS because it is confidential, you can read or delete messages; it goes directly to the user, to the objective. \\
\hline Quote 3 & Messages should not be as sales promotions. Because when I get those kind of messages on my phone, I do not even read them. \\
\hline Quote 5 & $\begin{array}{l}\text { Do not send excessive messages such as some local companies do; they send every day and sometimes early in the morning; } \\
\text { messages should be sent only in specific days and time. }\end{array}$ \\
\hline Quote 6 & $\begin{array}{l}\text { You can explain that from this date they will start receiving messages from a specific number, regarding the objective of your study } \\
\text { or program, so messages will not catch them by surprise. }\end{array}$ \\
\hline Quote 7 & $\begin{array}{l}\text { Use a general language, because someone gossipy can take your cell phone and read "free HIV testing" then they could think you } \\
\text { are sick. }\end{array}$ \\
\hline Quote 10 & Messages should be as those headlines of newspapers: concise and interesting. After that you can add testing hours, for instance. \\
\hline Quote 11 & Remind people you are providing HIV testing for free and that it will be confidential. \\
\hline Quote 12 & $\begin{array}{l}\text { You should not send a message like this: remember that you need to get tested for HIV...you can write, instead: remember you can } \\
\text { make an appointment at www.example.org... something more general. }\end{array}$ \\
\hline Quote 13 & You know what kind of messages nobody reads? Messages that are always the same, they need to change over time. \\
\hline Quote 14 & A good message would be "Health, life and love... if you love your partner, take care of you." Everyone wants love. \\
\hline Quote 15 & It cannot be too long. You can add "If you have any question or need further information, log into www.example.org" \\
\hline Quote 16 & Funny stuff always helps. For example, the commercials I remember the most are the ones that included something comical. \\
\hline
\end{tabular}

week. In South Africa, researchers testing whether frequency of sending messages had an impact on HIV testing found that sending SMS messages three days apart was effective in promoting HIV testing [13]. Other studies among MSM suggest that different frequency and timing to receive messages depending on the behavior change they wanted to achieve. For example, in a study to reduce methamphetamine use among MSM, the research staff had up to four text messaging conversations per day, per participant, because MSM required a much closer follow-up to not engage in negative behavior [11].

Using creative messages is also important to achieve our intervention objectives. We created health messages with humorous content, such as SMS 6 that was based on the way of talking of the "Magic Guinea Pig", a Peruvian icon that was part of a successful Peruvian bank campaign [25]. Also, we used symbols like + or $=$ to make our messages more fluid (SMS 16) and we phrased some messages as questions to prompt participant's attention (SMS 5, 10 and 17).

We developed a total of 18 messages that provided information, motivation and behavioral skills to help participants make the decision of getting tested for HIV. De Tolly et al. found a significant higher rate of HIV testing among participants who received 10 motivational messages for a 3-week intervention compared to groups who received 3 motivational messages, 10 informational messages or 3 informational messages, showing that motivational messages are a key component and that there is a minimum number of
SMS that are required [13]. We did not stratify text messages by age or self-identification because we found similar results across the focus groups of different age strata (18-24 and 25 and older) and self-identification.

Our study has some limitations. First, we have included among our participants only MSM younger than 40 years old, thus we cannot extrapolate our results to MSM of all ages Second, we have recruited the majority of our population at a community-based organization where gay men with higher educational attainment are more likely to attend. Third, all our participants were from Lima, thus we cannot extrapolate our results to MSM from other regions of Peru.

Our strengths are that we reached saturation in our study as many of the responses were similar among participants, and that the information collected will be used for an intervention whose target population are participants from the same age, education level and place of residence as participants of this research study.

To our knowledge this is the first study in Latin America designed to explore SMS content and features to motivate HIV testing among MSM. This study is important because it goes one step forward by designing and tailoring a set of messages based on formative research. The next step is to implement the delivery of these text messages as part of a multi-component intervention that will include online videos, email, chat and SMS to motivate HIV testing among MSM. 
Table 2. Text Messages Organized by Reasons for Not Getting Tested and Component of the IMB Model

\begin{tabular}{|c|c|c|c|}
\hline $\begin{array}{l}\text { Number } \\
\text { of SMS }\end{array}$ & SMS & Reason for Not Getting Tested & $\begin{array}{l}\text { Component of the } \\
\text { IMB Model }\end{array}$ \\
\hline SMS 1 & $\begin{array}{l}\text { Welcome to Tu Nexo. We will be sending health-related messages for } \\
\text { FREE from now on. Visit www.tunexo.org }\end{array}$ & Complementary message (welcome) & Information \\
\hline SMS 2 & $\begin{array}{l}\text { Whatever happens, you will be ok with Tu Nexo. Visit } \\
\text { www.tunexo.org. You decide! }\end{array}$ & $\begin{array}{l}\text { Fear of negative consequences/Fear of } \\
\text { discrimination and lack of support }\end{array}$ & Motivation \\
\hline SMS 3 & $\begin{array}{c}\text { Having a healthy partnership starts out by getting tested. Visit } \\
\text { www.tunexo.org. You decide! }\end{array}$ & Lack of risk perception & Motivation \\
\hline SMS 4 & $\begin{array}{l}\text { Remember, now in Peru treatment is FREE. Visit www.tunexo.org } \\
\text { You decide! }\end{array}$ & Lack of knowledge about free treatment & Information \\
\hline SMS 5 & $\begin{array}{l}\text { Getting ready for partying? Make sure to take condoms. A message } \\
\text { from your friends at www.tunexo.org }\end{array}$ & Lack of risk perception & Information \\
\hline SMS 6 & $\begin{array}{l}\text { No scissors, no teeth! Condoms must be open with your fingers. A } \\
\text { message from your friends at www.tunexo.org }\end{array}$ & $\begin{array}{l}\text { Complementary message (HIV } \\
\text { prevention) }\end{array}$ & Information \\
\hline SMS 7 & $\begin{array}{l}\text { Always use WATER-based lubricants. Oil-based lubricants can break } \\
\text { condoms. A message from your friends at www.tunexo.org }\end{array}$ & $\begin{array}{c}\text { Complementary message (HIV } \\
\text { prevention) }\end{array}$ & Information \\
\hline SMS 8 & $\begin{array}{l}\text { Do not save condoms in your wallet or in your back pocket because } \\
\text { they can be damaged. A message from www.tunexo.org }\end{array}$ & $\begin{array}{l}\text { Complementary message (HIV } \\
\text { prevention) }\end{array}$ & Information \\
\hline SMS 9 & $\begin{array}{l}\text { Remember that Tu Nexo is confidential; you do not need to give your } \\
\text { name or your ID. Visit www.tunexo.org }\end{array}$ & Fear of discrimination and lack of support & Information \\
\hline SMS 10 & $\begin{array}{l}\text { What important things in life can be done in } 20 \text { minutes? Get tested } \\
\text { and start taking control of your body and health. Do it at } \\
\text { www.tunexo.org }\end{array}$ & Fear of negative consequences & $\begin{array}{l}\text { Motivation/Behavioral } \\
\text { Skills }\end{array}$ \\
\hline SMS 11 & Getting tested costs nothing. With Tu Nexo it's FREE. You decide! & Lack of knowledge about free testing & $\begin{array}{l}\text { Motivation/Behavioral } \\
\text { Skills }\end{array}$ \\
\hline SMS 12 & $\begin{array}{l}\text { With treatments there are no differences. Get tested. Visit } \\
\text { www.tunexo.org }\end{array}$ & Fear of negative consequences & $\begin{array}{l}\text { Motivation/Behavioral } \\
\text { Skills }\end{array}$ \\
\hline SMS 13 & $\begin{array}{l}\text { Get tested. With Tu Nexo staff you will not be alone. Visit } \\
\text { www.tunexo.org }\end{array}$ & Discrimination and lack of support & $\begin{array}{l}\text { Motivation/Behavioral } \\
\text { Skills }\end{array}$ \\
\hline SMS 14 & Come get tested with someone you trust. Visit www.tunexo.org & Discrimination and lack of support & $\begin{array}{l}\text { Motivation/Behavioral } \\
\text { Skills }\end{array}$ \\
\hline SMS 15 & $\begin{array}{l}\text { Genital wounds or blisters put you at risk. If you have had them, get } \\
\text { tested just to be doubly sure. Get an appointment in www.tunexo.org. } \\
\text { You decide! }\end{array}$ & Lack of risk perception & $\begin{array}{l}\text { Information/Motivation } \\
\text { /Behavioral Skills }\end{array}$ \\
\hline SMS 16 & $\begin{array}{c}\text { Sex }+ \text { alcohol }=\text { risk. If this happened to you, it is time to be doubly } \\
\text { sure. You decide! }\end{array}$ & Lack of risk perception & Information/Motivation \\
\hline SMS 17 & $\begin{array}{l}\text { Have you been sexually active? Get tested and enjoy being well. } \\
\text { Protect yourself and protect them. Visit www.tunexo.org }\end{array}$ & Lack of risk perception & $\begin{array}{l}\text { Information/Motivation } \\
\text { /Behavioral Skills }\end{array}$ \\
\hline SMS 18 & $\begin{array}{l}\text { If you had intercourse without protection, get tested. Visit } \\
\text { www.tunexo.org }\end{array}$ & Lack of risk perception & $\begin{array}{l}\text { Information/Motivation } \\
\text { /Behavioral Skills }\end{array}$ \\
\hline
\end{tabular}

\section{CONFLICT OF INTEREST}

The authors confirm that this article content has no conflicts of interest.

\section{ACKNOWLEDGEMENTS}

The authors would like to thank Amy Thompson for editorial assistance and the staff of Epicentro for their support in the development of this project. This study was supported by the Fogarty International Center/National Institutes of Health (FIC/NIH) grant R01 TW008398 to Magaly Blas and QUIPU: The Andean Global Health Informatics Research and Training Center, a FIC/NIH funded grant D43TW008438-0109. The funders had no role in study design, data collection and analysis, decision to publish, or preparation of the manuscript.

\section{REFERENCES}

[1] UNAIDS. Report on the global AIDS epidemic 2010. Available from: http://www.unaids.org/globalreport/documents/20101123_G lobalReport_full_en.pdf [Accessed: 10 October 2012]

[2] UNGASS (2012) Country progress report: Peru. Available from: http://www.unaids.org/en/dataanalysis/knowyourresponse/countryp rogressreports/2012countries/ce_PE_Narrative_Report.pdf [Accessed: 10 October 2012]

[3] Kusunoki L, Guanira J, Navarro C, Velasquez C. Report of Monitoring the declaration of commitment on HIV/AIDS Peru. 2005. Available from: http://data.unaids.org/pub/Report/2006/2006 country_progress_report_peru_en.pdf [Accessed: 10 October 2012] 
[4] OSIPTEL. Telecommunications in Peru, Statistics (Option: "Densidad por departamento"). Available from: http://www.osiptel.gob.pe/WebsiteAjax/WebFormgeneral/sector/w frm Consulta Informacion Estadisticas.aspx?CodInfo $=13478 \& \mathrm{Co}$ $\mathrm{dSub} C \mathrm{Ca}=864 \&$ TituloInformacion $=2 . \% 20$ Indicadores $\% 20 \mathrm{del} \% 20 \mathrm{~S}$ ervicio $\% 20 \mathrm{M} \% \mathrm{C} 3 \% \mathrm{~B} 3$ vil\&DescripcionInformacion [Accessed: 10 October 2012]

[5] Blas MM, Alva IE, Cabello R, et al. Internet as a tool to access high-risk men who have sex with men from a resource-constrained setting: a study from Peru. Sex Transm Infect 2007; 83(7): 567-70.

[6] Menacho L. Evaluating an Internet-based behavioral intervention to decrease risk behaviors for HIV acquisition among men who have sex with men in Peru. Unpublished master's thesis, University of Washington, Seattle 2010.

[7] Curioso WH, Kurth A. Access, use and perceptions regarding Internet, cell phones and PDAs as a means for health promotion for people living with HIV in Peru. BMC Med Inform Decis Mak 2007; 7: 24

[8] Curioso WH, Alex Quistberg D, Cabello R, et al. "It's time for your life": How should we remind patients to take medicines using short text messages? AMIA Annu Symp Proc 2009; 2009: 129-33.

[9] Lim MS, Hocking JS, Hellard ME, Aitken CK. SMS STI: a review of the uses of mobile phone text messaging in sexual health. Int J STD AIDS 2008; 19(5): 287-90.

[10] Warwick Z, Dean G, Carter P. B safe, B sorted: results of a hepatitis B vaccination outreach programme. Int J STD AIDS 2007; 18(5): 335-7.

[11] Reback CJ, Grant DL, Fletcher JB, et al. Text messaging reduces hiv risk behaviors among methamphetamine-using men who have sex with men. AIDS Behav 2012; 16(7): 1993-2002.

[12] Reback CJ, Ling D, Shoptaw S, Rohde J. Developing a text messaging risk reduction intervention for methamphetamine-using msm: research note. Open AIDS J 2010; 4: 116-22.

[13] de Tolly K, Skinner D, Nembaware V, Benjamin P. Investigation into the use of short message services to expand uptake of human immunodeficiency virus testing, and whether content and dosage have impact. Telemed J E Health 2012; 18(1): 18-23.
[14] Lewis MA, Uhrig JD, Bann CM, et al. Tailored text messaging intervention for HIV adherence: a proof-of-concept study. Health Psychol 2012. Apr 30 [Epub ahead of print].

[15] Mbuagbaw L, Thabane L, Ongolo-Zogo P, et al. The Cameroon mobile phone SMS (CAMPS) trial: a protocol for a randomized controlled trial of mobile phone text messaging versus usual care for improving adherence to highly active anti-retroviral therapy. Trials 2011; 12: 5 .

[16] Blas MM, Alva IE, Cabello R, Carcamo C, Kurth AE. Risk behaviors and reasons for not getting tested for HIV among men who have sex with men: an online survey in Peru. PLoS One 2011; 6(11): e27334.

[17] Blas MM, Alva IE, Carcamo CP, et al. Effect of an online videobased intervention to increase HIV testing in men who have sex with men in Peru. PLoS One 2010; 5(5): e10448.

[18] Fisher JD, Fisher WA, Misovich SJ, Kimble DL, Malloy TE. Changing AIDS risk behavior: effects of an intervention emphasizing AIDS risk reduction information, motivation, and behavioral skills in a college student population. Health Psychol 1996; 15(2): 114-23.

[19] Fisher JD, Fisher WA. Changing AIDS-risk behavior. Psychol Bull 1992; 111(3):455-74.

[20] Derlega VJ, Winstead BA, Oldfield III EC, Barbee AP. Close relationships and social support in coping with HIV: a test of sensitive interaction systems theory. AIDS Behav 2003; 7(2):11929 .

[21] Barney GG, Anselm LS. The discovery of grounded theory: strategies for qualitative research. Chicago: Aldine Publishing Company 1967.

[22] Padgett D. Qualitative methods in social work research. $2^{\text {nd }}$ ed. Los Angeles, California: Sage Publications 2008.

[23] Grier S, Bryant CA. Social marketing in public health. Annu Rev Public Health 2005; 26: 319-39.

[24] Plant A, Montoya JA, Rotblatt $\mathrm{H}$, et al. Stop the sores: the making and evaluation of a successful social marketing campaign. Health Promot Pract 2010; 11(1): 23-33.

[25] BCP. Peruvian magical guinea pig campaign 2012. Available from: http://cuymagico.pe/conseguir-financiamiento.php [Accessed: 10 October 2012].

(C) Menacho et al:; Licensee Bentham Open.

This is an open access article licensed under the terms of the Creative Commons Attribution Non-Commercial License (http://creativecommons.org/licenses/by-nc/ $3.0 /$ ) which permits unrestricted, non-commercial use, distribution and reproduction in any medium, provided the work is properly cited. 